\title{
Enforcement of the Use of Cartography in Geography in High School
}

\section{José Falcão Sobrinho1*, Maria Raianede Mesquita Gomes², Marcos Venicios Ribeiro Mendes ${ }^{3}$, Maria Thays Menezes Silva ${ }^{3}$, Alvaro Andrade Dourado ${ }^{3}$}

\author{
${ }^{1}$ State University of Vale do Acaraú/UVA, Sobral, Brazil \\ ${ }^{2}$ Federal Institute of Education of Ceará/IFCE, Sobral, Brazil \\ ${ }^{3}$ Geography/UVA, Sobral, Brazil \\ Email: ^falcao.sobral@gmail.com
}

How to cite this paper: Sobrinho, J. F., Gomes, M. R. M., Mendes, M. V. R., Silva, M. T. M., \& Dourado, A. A. (2019). Enforcement of the Use of Cartography in Geography in High School. Creative Education, 10, 1242-1250.

https://doi.org/10.4236/ce.2019.106093

Received: May 8, 2019

Accepted: June 25, 2019

Published: June 28, 2019

Copyright () 2019 by author(s) and Scientific Research Publishing Inc. This work is licensed under the Creative Commons Attribution International License (CC BY 4.0).

http://creativecommons.org/licenses/by/4.0/

\section{(c) (i) Open Access}

\begin{abstract}
The following article has an objective to report the lived experience of the enforceability of cartography in geography. In each opportunity, this research has aimed its gaze to the content of urbanization attached to a cartographic knowledge, considering that it leads students to a comprehension of the geographical area and the reality of the world. At first, this work has been based on targeted literature reviews by developing practical activities using images from artificial satellites (Google Earth), according to the content from the textbook studied by the high school 2-year class at Jarbas Passarinho School. While applying such activities, it has been noticed some difficulties which both students and teachers have when dealing with cartography; however the proposed exercises made the content comprehension easy. Hence, such practical activities have reached its goals in doing mediation between geography and cartography, since it has contributed in a positive way in students' learning.
\end{abstract}

\section{Keywords}

Geography, Cartography, High School

\section{Introduction}

Historically, cartography was created before Christ due to the necessity of representing space, mainly by nomads, which used resources available to them such as clay, cave painting, papyrus and animal skin to represent environments and most of the time to the human group survival (Carvalho \& Araújo, 2008). Since then, cartography has been evolving along the years, principally with the 
technological advancement in the last decades, which ended up providing an information facility through artificial satellites to produce cartographical documents to the most diversified purposes.

Furthermore, it is also important to highlight that other fields use cartographical knowledge, such as geology, engineer, pedology, agriculture, navigation, tourism, architecture, urbanism, meteorology and among them geography.

For instance, from the teaching of geography, cartographical knowledge is engaged in the process of students' learning, considering that it leads students to a comprehension of the geographical area and the reality of the world, which was previously highlighted by Passini (1994) when he emphasized that "cartographical education or literacy to read maps should be considered as important as the literacy to read texts", initially "[...] it means to prepare students to make and read maps".

According to this thinking, Filizola (2009), says that the organization of cartography in schools is carried out in an outdated and piecemeal form, besides having its learning, most of the time, performed in a mechanical way. This is a consequence of the fact that students rarely perform activities related to the construction or production of maps, even less, the contents establish a relation to the handling of cartographical representations.

Thus, as the objective of the activity, it is stressed the reality of areas students live through activities to map sectors of services offered close to the school and neighborhood where most of them live in, such as health center, supermarkets, drugstores, bakeries and urban mobility.

In this context, this work has been developed from the theme of urbanization attached to the teaching of cartography, considering the high school 2-year class at Jarbas Passarinho School (Figure 1), in Sobral, Ceará, Brazil.

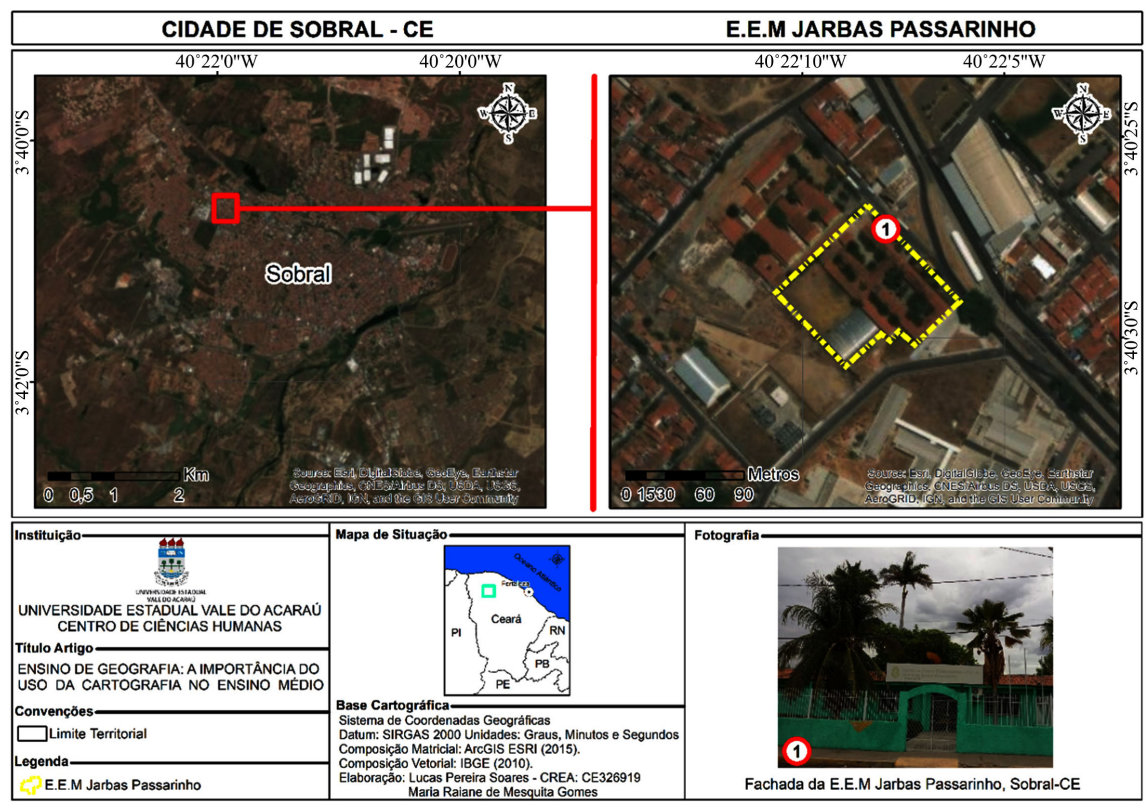

Figure 1. Localization map of the field of study. Photo by Author. 


\section{The Teaching of Cartography and Its Dynamics of Representation}

According to the Instituto Brasileiro de Geografia e Estatística (IBGE-Brazilian Institute of Geography and Statistics), in 1999, cartography “is a set of studies and scientific, technical and artistic operations, which having as basis the analysis of existing documents or results from direct observations, seeks to elaborate maps and other forms of graphical expressions besides representations of objects, physical and socioeconomics environments, elements and phenomena as well as its uses", fact which is applied in the teaching in universities.

Moreover, the definition adopted by the International Cartographic Association in 2003, the concept of cartography becomes wider since it comprises it as the set of studies and scientific, artistic and technical operations which intervene from the exploration of documents or results of direct observations, in view of the elaboration and establishment of maps, plans and other forms of expression, as well as its use.

In a geographical context, Souza and Katuta (2001), state that a definition for cartography, among many others previously presented:

"It transpires a common concept for cartography. art, method and technique to represent the Earth surface and its phenomena. We point out that, as art, we understand the plastic quality (aesthetic) of representation, the use of colors, the plots, the strokes, as technique, its strokes and information accuracy; as method, the possibility of reflection, analysis and interpretation of qualities in a charted information".

Having said that, in a geographical context the result of a cartographical product is the map, which is a form to convey information.

In addition, it is realized that the historical evolution of cartography shows us that man always have been concerned to record its space, lifestyle, culture and cartography in caves and mountain walls, such representation is known as rock paintings. These are as quite old recordings as the necessity for societies survival and preced the birth of symbols and signs.

In Gurgel's studies (2012), Europeans used portolan charts, known since the Sigle XIII, and from 1569 they started using maps drawn by the cartographer Gerhard Mercator. It is worth noting that maps, despite of the deformation in the latitudinal measures due to the projection employed by cartographers, did not concern the Europeans which were strongly involved in the expansion of the European colonial empire. Even because such deformations extolled Europe measures and limited the dimensions in great continents (Africa, South America), what could be an additional argument of supremacy to European colonist countries regarding those great explored continents (Africa, America).

It is the breakthrough in maritime trade that makes wider the need for maps, more and more important and accurate; it was made possible by the invention of different technical instruments which gave more accuracy to colonizers in their exploring trips. 
Compass and astrolabe, among other instruments, was quite important not only to great navigations but also to cartography.

It is noticed that since the beginning of the systematization of geographical knowledge, cartography has been fixed as an assisting tool essential to the progress of geographical science.

In Brazilian geography, when teaching gained a wider dimension, in 1930, Delgado de Carvalho published the book Methodology of the Geographical Teaching, followed by an illustrative map of its information.

Throughout the history of geography teaching guided on a traditional pedagogy, the use of maps was to portray landscapes, populational indicators and other descriptive information. The adopted practice was based on memorization and on map drawings. These were the dynamics in classrooms.

On one hand, pragmatic geography searched for new techniques and language capable of accomplishing planning tasks, being one of its aspects the use of mathematical instruments to analyze the geographical space, also including maps, which are still mathematical tools. According to Girardi (2000), it survives in pragmatic geography the cartographical representations as a support to the construction of mathematical modelling. However, in the renewal moment occurred in the 1970s, a reading skewed of what would be the proposal of critical geography made several geographers quit, erroneously, cartographical tools.

Additionally, in accordance with the author, as part of critical geography, the situation was different. Yves Lacoste's book-Geography, it serves, first, to make war, published originally in 1976, harshly criticizes the method, procedure and political position of geography until then constituted, since it would reveal power relations institutionalized both in "teachers' geography" and in "larger states' geography", accordingly to Lacoste.

Souza and Katuta (2001) show that cartography was associated to state power, put as a representant to traditional geography. In the speech of critical geography, maps were an image of domain. Besides producing its dropout, this fact also produced a prejudice regarding to subjects which were considered technical.

To Girardi (2000), there is a paradox in the disruption moment since the critical geography had as support theories about both verbal and non-verbal communication. There were conditions, though, to analyze critics of cartographical representations by geography, seeing the map as a mean of communication of geographical phenomena, but it is exactly at this point that occurs the separation. The author points the Graphical Semiology, by Jacques Bertin, in 1967, as the only project to systematize the construction rules for reasonable images to the communication of information in a scientific character.

It is worth mentioning that the treatment given to cartography leads us to an understanding to reflect on theories in which they are based on, so we can understand the dynamics adopted in classrooms alongside the theoretical and methodologic concepts inserted in geography.

In this context, we associate Simielli's understanding (1999), when he says that maps allow us to have spatial domain and an overview of phenomena which 
take place in certain space. In our or in citizens' daily lives, it is possible to have a reading of space through information and, in cartography, through different forms to represent such information. In addition, it is capable to have a variety of products representing different information to different objectives: tourism maps, planning maps, road maps, mineral maps, geological maps, among others.

\section{The Importance of Cartography in High School}

The research aims to use cartography as a pedagogical tool which boosts students learning on multiple topics besides assisting teachers in geography classes, hence, creating a closer dialogue between teacher and student.

In this way, the rising of microcomputer in the 1980s and afterward the internet was essential, since it made easier the action of the cartographical science by providing maps in websites and satellite images, data, georeferenced maps which is available to the public, including, as an educational resource by teachers (Alves, 2013).

Inside this framework, the main focus is to provide students with a relation between their book's topics and their reality, from clippings of satellites images (Google Earth) which will be given to each group. This way, it is expected that from their background knowledge they can identify the principal economic sectors, like trading establishments and other services available close to their school and neighborhood, reaching through it all, a meaningful learning.

In this sense, Castellar (2014: p. 201), highlights the importance of the use of cartography when teaching geography:

The use of cartographical language as a groundbreaking methodology is to make it part essential to the geographic education, to the construction of students citizenship in an extent that will allow them to understand geographical contents and concepts through a language which will translate abstract observations into concrete representations of reality.

For this reason, we decided to work on the topic of urbanization associating the teaching of social cartography by enabling the visual language which is essential to the process of a meaningful teaching and accordingly to Castellar (2014), establishing the relation between cartography and geographical contents is fundamental to students so they can understand the concepts worked along their schooling.

Furthermore, cartography is important due to its considerable contribution with a spatial view that, for Castellar (2014), students come to a better observation of the places where they live, additionally, they understand the construction and changings in landscapes.

\section{Methodology}

At first, the applied methodology was guided by targeted bibliographic reviews and by the development of practical activities using artificial satellite images (Google Earth), regarding to the content from the textbook used by the high 
school $2^{\circ}$ year students at Jarbas Passarinho School, and applied with the assistance of the responsible geography teacher.

The proposed content for the application of a practical activity addressed in the high school 2-year textbook, is presented in a descriptive form that subsequently the class becomes boring and students distracted. Considering this, students were proposed to map the main economic sectors such as trading establishments and other services offered next to the areas in question, involving them in the activity, delivering dynamism to the class and turning them into agents in the construction of knowledge.

Before starting the activity properly, a class was conducted to explain the basic elements which make up a map, which are: title, subtitle, symbol, scale, source, orientation and geographic coordinates which each group would have to put in the clipping of satellite images they have received.

In the end of the activity, a questionnaire was applied so students could evaluate this activity and give suggestions to make classes more interesting.

\section{Results}

The results collected from the application of the activity enabled a visualization of some difficulties which both students and teachers have when dealing with contents of geography. Cartography becomes important in the teaching of geography given that it provides interdisciplinarity and presents a bunch of methodological forms to work the contents.

Teachers from elementary and high school present difficulties when working with cartography, and it makes them not to link the teaching of cartography to the rest of the contents of geography. The reason for this is an outdated initial training, in which basic means were not introduced so they could go over the subject, and like Girard (2011) said, in most of the time it is the result of a disarticulated and piecemeal curriculum.

In view of that, it is worth emphasizing some difficulties during the application of the practical activity, such as: poor infrastructure of the institution, the absence of a computer laboratory, just few computers working, besides being small, the classroom environment has noisy ceiling fan, making the class unbearable to both students and teachers.

As formerly mentioned in methodology, it was conducted an expository class and talked about cartography presenting concepts, orientations and elements found on a map, chart, etc. In this process, it could be seen difficulties on the part of some students about the class, but a few others showed a knowledge about the topic and they did not have difficulties while carrying it out.

Therefore, it was necessary more than one class to apply the activity, being the second class directed to the questionnaires with students regarding the content to evaluate their learning.

The activity had as objective that students mapped areas of services next to the neighborhood and school, using in the subtitle the symbols to represent build- 
ings, rivers, etc., as mentioned in the theoretical class to elaborate maps. After that, students were divided in groups, each one received an image and started working in the construction of a map. Figure 2(a) and Figure 2(b) show students carrying out the activity.

Initially, students had demonstrated difficulty in recognizing the area, but then they recognized the image originated from Google Earth and managed to identify all the points indicated by the intern and the teacher, as well as presented additional points suggested by themselves. Figure 3(a) and Figure 3(b) represent the satellites images which were used by students to identify urban apparatus.

In the end, some tasks about the activity were given to students. What is more, open questions were asked to collect their opinion.

The analysis of the questionnaires reveals that students evaluated in a positive form the practical activity, they also mentioned other positive points like teamwork and dynamism, what according to them improved their knowledges about the approached content.

Besides, based on the questionnaires, the use of satellite images integrated into cartographic issues and urbanization was important to understand the reality lived by students, that is, cherishing what is seen daily by them while conceiving a geographical view of landscapes, an explanation about what is perceived guided by a development of a view conceiving landscapes and its resources.

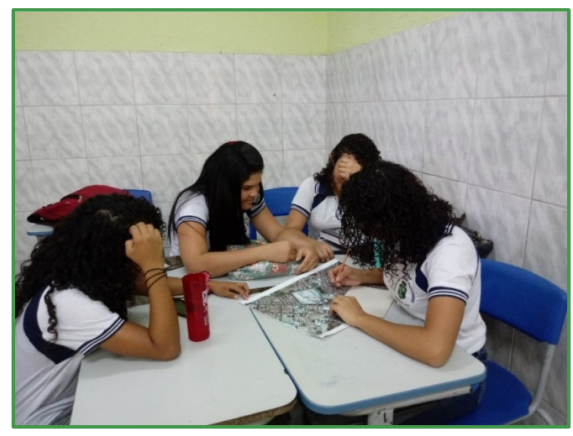

(a)

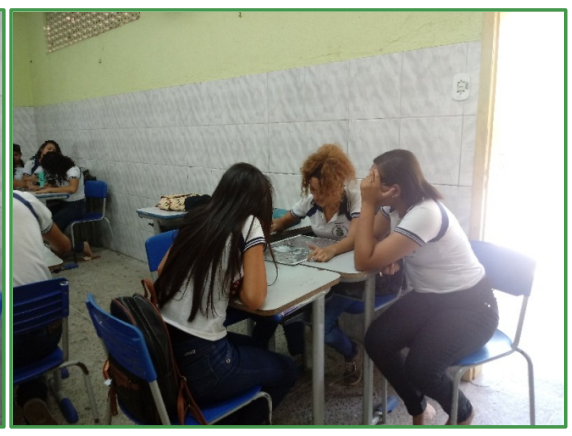

(b)

Figure 2. Students developing the activity. Photo by Gomes (2018).

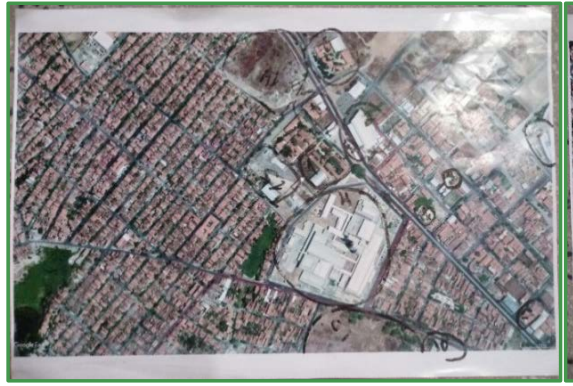

(a)

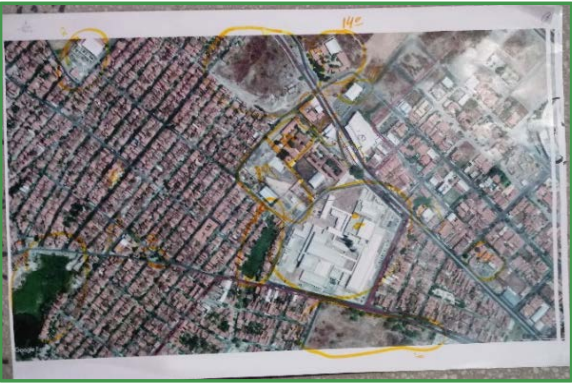

(b)

Figure 3. Satellites images used by students to identify urban apparatus. Photo by Gomes (2018). 


\section{Conclusion}

Therefore, the practical activity reached its goal by mediating urbanization and cartography, contributing positively in students' learning considering they came to understand the importance of cartographical science to the spatialized view and the process of space construction and modification.

In respect of it, the material used has a low cost, is affordable so teachers can develop other application methodologies in the teaching of cartography and geography, enhancing the participation and interaction among students.

The use of satellite images when teaching geography is proved to be something positive, being important the use of these images as an educational resource in enhancing such teaching, pursuing a suitable work to the study of urban dynamics in a certain area.

It is necessary to the teaching of geography the use of technological tools GPS, Geographical Information System-SIG, amongst others, in reason that classes become more dynamic and attractive to students, which in various cases cannot develop the expected knowledge due to the high level of abstraction presented in many geographical topics.

\section{Acknowledgements}

To FUNCAP/CNPq for the support through the announcement 22/2014 e to the scholarship students from scientific initiation of LAPPEGEO/UVA.

\section{Conflicts of Interest}

The authors declare no conflicts of interest regarding the publication of this paper.

\section{References}

Alves, T. S. (2013). Cartografia da ação social: entre disputas e ações no ensino da Geografia. In V Fórum Internacional de Pedagogia, 2013, Vitória da Conquista. Anais Fiped V. Campina Grande.

Carvalho, E. A., \& Araújo, P. C. (2008). História da Cartografia. Natal, RN: Edufrn.

Castellar, S. V. (2014). A cartografia e a construção do conhecimento em contexto escolar. In R. D. Almeida (Ed.), Novos rumos da cartografia escola: Currículos linguagem e tecnologia. São Paulo: Contexto.

Filizola, R. (2009). Didática da Geografia: proposições metodológicas e conteúdos entrelaçados com a avaliação. Curitiba: Base Editorial.

Girard, E. P. (2011). A Construção de uma Cartografia Geográfica Crítica. In Revista Geográfica de América Central. Número Especial-EGAL. Costa Rica. II Semestre.

Girardi, G. (2000). Leitura e mitos em mapas: um caminho para repensar as relações entre Geografia e Cartografia. Geografares, 1, 41-50.https://doi.org/10.7147/GEO1.1162

Gurgel, A. C. (2012). Mercator e sua contribuição à cartografia e ao estudo dos mapas. Dissertação de Mestrado de História da Ciência. São Paulo: Pontifica Universidade católica. 
IBGE-Instituto Brasileiro de Geografia e Estatística (1999). Noções básicas de Cartografia. Rio de Janeiro: IBGE.

International Cartographic Association (2003). A Strategic Plan for the International Cartographic Association 2003-2011. Durban: ICA.

Passini, E. Y. (1994). Alfabetização cartográfica e o livro didático: uma análise crítica. Belo Horizonte: Editora Lê.

Simielli, M. E. R. (1999). A cartografia no ensino fundamental e médio. In Carlos, Ana Fani Alexandro. A Geografia em sala de Aula. São Paulo: Editora Contexto.

Souza, J. G., \& Katuta, A. M. (2001). Geografia e conhecimentos cartográficos: A cartografia no movimento de renovação da geografia brasileira e a importância do uso de mapas. São Paulo: Editora UNESP. 